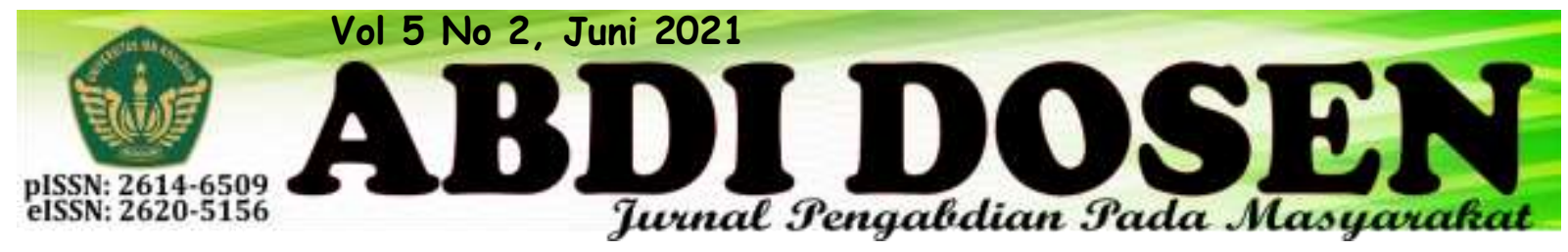

\title{
SOCIALIZATION FOR THE IMPLEMENTATION OF E-LEARNING TEACHING MODELS FOR TEACHERS AND EDUCATION STAFFS AT SMA SULTAN AGUNG PEMATANGSIANTAR
}

\author{
Sherly $^{1}$, Herman $^{2 *}$, Fitria Halim ${ }^{3}$, Julyanthry ${ }^{4}$, Edy Dharma $^{5}$, Ridwin Purba ${ }^{6}$, Rosita Manawari \\ Girsang $^{7}$ \\ sherlychi12345@gmail.com ${ }^{1}$, herman@uhn.ac.id 2*, fitriahalim2839@gmail.com ${ }^{3}$, yoe.lianthry@gmail.com ${ }^{4}$, \\ edydharma111@gmail.com ${ }^{5}$, nridwinpurba@yahoo.com ${ }^{6}$, rosita.girsang @ gmail.com $^{7}$ \\ Sekolah Tinggi Ilmu Ekonomi (STIE) Sultan Agung Pematangsiantar ${ }^{1,3,4,5}$ \\ Universitas HKBP Nommensen, Medan ${ }^{2}$ \\ Universitas Simalungun, Pematangsiantar ${ }^{6,7}$
}

\begin{abstract}
This community service had the aim of improving and developing teachers' online teaching learning processes for students. Rapid shifts in different aspects of life are one of the hallmarks of the globalization period. One of them is the advancement of science and technology, especially Information and Communication Technology (ICT), which has a significant positive impact on educational development. Teachers, in particular, need multimedia in the learning process. Educators play a critical role in guiding the learning process in the classroom. Teachers would find it easier to conduct online learning as a result of this socialization. Lectures with presentations, as well as drills or practice, are used in this community service project. After completing the activity, the researchers discovered the following findings: 1) Zoom, Google Classroom, and WhatsApp were chosen to be used by teachers in the teaching learning process; 2) Teachers agreed that e-learning was an important method of learning, 3) The soft skills of teachers in the use of certain e-learning resources improved, and 4) Teachers were willing to agree that the online teaching learning method was a part of teaching learning.
\end{abstract}

Keywords: E-learning, socialization, teaching models, online

\section{INTRODUCTION}

Corona Virus Disease 2019 or also known as COVID-19 has given a great impact to human's life since its existence in the end of December 2019. The COVID-19 has been spread out through lots of countries, including in Indonesia. The first time case found in Indonesia was in the end of March 2020. Since its' effect and existence, government finally made a policy to stop all activities in some places, especially places that have crowded people such as mall, church, school, mosque, and so forth. Schools in Indonesia are one of the sectors where learning and teaching process cannot be done by face-to-face process like usual. But when the activities were closed, lots of schools are trying to continue the teaching learning process through online models. This is in line to statement by Marzuki, Syahrial and Rusmono (2020:24). They stated that the quality of education cannot be improved without the essential activity through learning process in education. The problems are becoming 
complicated since not all schools are ready and well prepared to have teaching and learning process online, especially for the schools in small city like in Pematangsiantar, North Sumatera Province.

There are lots of private and government schools in the city. Since the teaching learning process face-to-face was stopped because of COVID-19, the schools demanded the teachers to continue the teaching learning process via online. Tigowati, Efendi, and Budiyanto (2017) stated that e-learning as one of the IT-based learning model has been able to overcome the constraints of time and distance in conventional learning through a full onlinebased learning process (Thao et al, 2021). Learning models such as e-learning, blended learning, and other virtual learning are some examples of IT-based learning which have been encountered in vocational high schools or universities in the IT field to support the learning process. Those learning models can work well only if they are supported by some factors such as

\section{RESEARCH METHODOLOGY}

This community service event was conducted by the method of a socialization that covered the method of lecturing and practice. The lecturing was done by the team of community service with the presentation through PowerPoint with the topics of Future Online Teaching Models. Then, the presenters explained some of popular technologies used as learning models in the form of e-learning which covered Edmodo, Google Classroon, Zoom, Atutor, Quipper, and so on. The purpose of this community service was to introduce and socialize the learning media models to all teachers in SMA Sultan Agung Pematangsiantar. This socialization was hoped to empower and give more facilities/platforms, teaching media, teaching materials, and adequate types of tests. Not only the factors mentioned above, but also the learning models can be implemented better if the human resources, teachers, are active and good in using the IT-based learning. Zain and Jumadi (2018) in their research stated that learning models, such as blended learning that still had not been maximally applied, especially in the learning process in some senior high schools or vocational high schools because of the selection of platform types that had not been right, the content of teaching materials was incomplete, and the unsuitable digital tests that gave bad impact that students were lack of understanding in depth about the material learned. Therefore, the researchers in this case would like to socialize and the aims to find out the suitable IT-based learning models used by the teachers in doing the blended learning through all teachers in SMA Sultan Agung schools in Pematangsiantar city.

information for teachers in using the suitable e-learning when teaching learning process in order to achieve the best achievement in the teaching and learning process for students. The lecturing was supported by some instruments such as laptop, LCD, WI-FI, speaker and others. Hence, the lecturing was continued to the practice/applying method to the e-learning models in order to optimize the e-learning better. The participants were given a time to discuss a suitable e-learning model, then the selected e-learning was to be trained for the better use of the e-learning itself. This community service was conducted on Thursday, 9 July 2020. There were thirtyseven teachers and for about 4 education 
staffs in this socialization. The activity was done online through zoom meeting since at the time, COVID-19 stroke and any activities were forbidden to be done. This activity was successully be held and

\section{RESULT AND DISCUSSION}

After conducting the method of lecturing and practice/implementation of the selected e-learning, there were some results depicted. This socialization was really useful for teachers in introducing the e-learning teaching models for teachers since teachers were only conventionalteaching-oriented before COVID stroke and made everything became different including in education itself. The selected elearnings to be suitable used in SMA Sultan Agung Pematangsiantar were zoom application, google classroom, and WhatsApp. Teachers were agree to accept the e-learning model learning effective in giving evaluation for students such as the evaluation for assignment and test by googleform. This evaluation really helps teacher in examining all the evaluation given to students. Implementing the online conducted with permission of Lembaga Penelitian dan Pengabdian Masyarakat (LPPM) or known as Research and Community Services Institutes of STIE Sultan Agung Pematangsiantar, Indonesia.

attendance list became more effective. The teachers were easy to check the attendance of the students from the online attendance list from google classroom. Through this socialization, teachers' soft skills in using some e-learning tools became better in order to support the teaching learning process. This e-learning socialization also changed teachers' mind to be open-minded in accepting that online teaching learning process was not as difficult as being thought and was easy to be planned and implemented

The following images were some of the procedures of creating assignment for students that can be used by teachers in using google classroom when doing the community services at SMA Sultan Agung Pematangsiantar.

\section{Cara mengisi tugas untuk siswa}

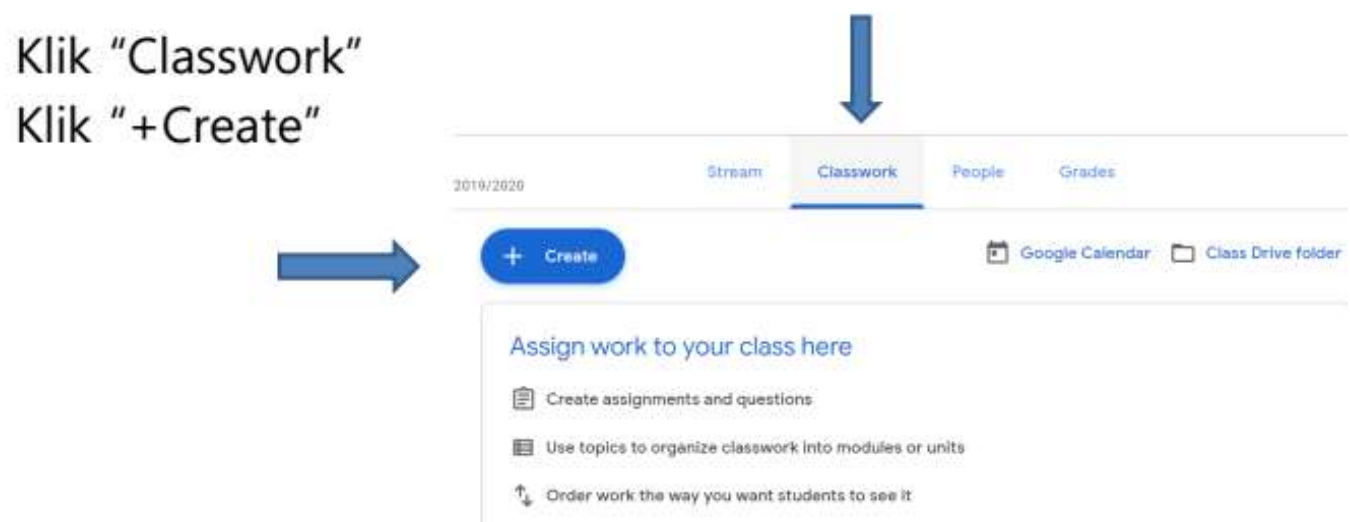

Image 1. How to create assignment for students 


\section{Pilih "Assignment"}

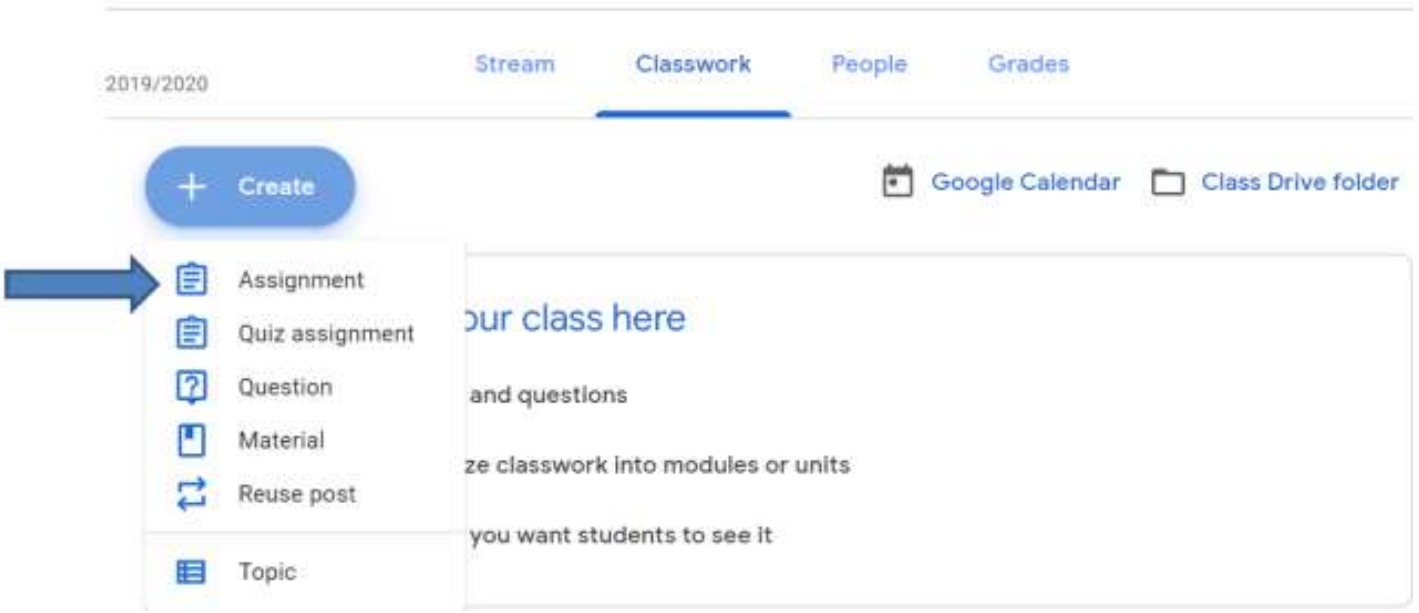

Image 2. Procedures in creating assignment via Google Classroom

Isilah tugas untuk siswa sesuai waktu tempo pengumpulan tugas dengan meng klik "Due" dan lampirkan materi (soal latihan dll) dari komputer dengan meng klik "file" dan "save" jika selesai

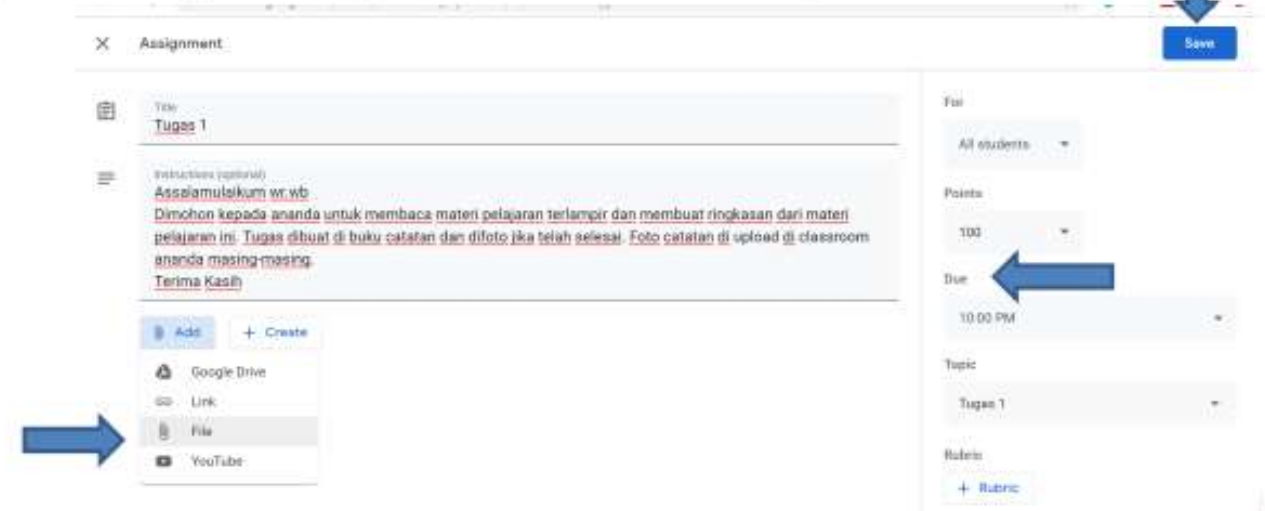

Image 3. Procedures in setting date and time for the assignment submission

\section{Tugas sudah selesai diposting di Classroom}

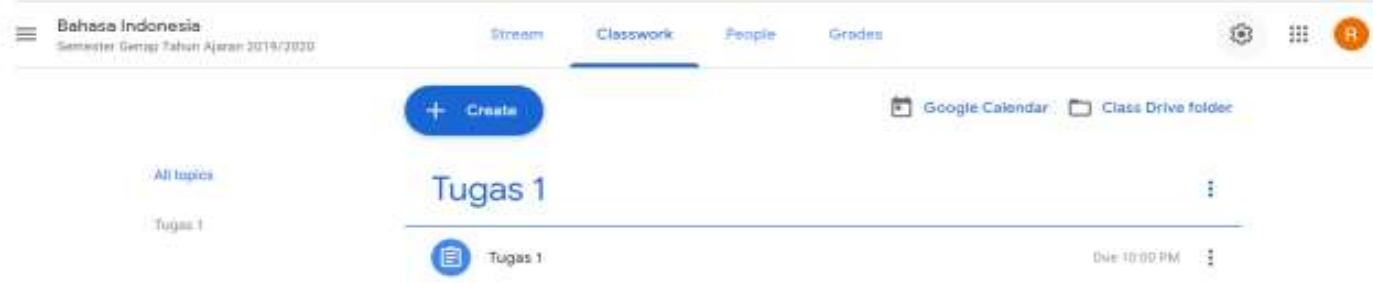

Image 4. Final Procedures in creating assignment in Google Classroom 


\section{CONCLUSION}

Online learning socialization for teachers and education personnel of SMA Sultan Agung Pematangsiantar is really helpful since the medias introduced were still unfamiliar and new for some of them. This community service done here certainly gave a new horizon for teachers and education personnel to assemble a more effective and more innovative online learning process. The ability in teaching and learning process conventional or up-to-date should be gained by teachers nowadays in order to achieve the better achievements or results. No one ever imagines that the model

\section{ACKNOWLEDGEMENT}

This socialization for implementing e-learning teaching models for teachers is permitted by Research and Community Services Institutes (Lembaga Penelitian dan

\section{REFERENCES}

Marzuki, I, Syahrial, Z. and Rusmono. (2020). How to Develop Blended Learning Educational Evaluation Courses Islamic Religious Education Study Program. Universal Journal of Educational Research 8(3A): 24-34, 2020.

DOI:

$$
\text { 10.13189/ujer.2020.081404 }
$$

Tampubolon, B., Christanto, L. M. H., Anasi, P. T. and Adlika, N. M. (2021). Pelatihan Pembelajaran Daring Pada Guru-Guru Geografi di Kabupaten Kubu Raya. Dedication: Jurnal Pengabdian Masyarakat, Volume 5, Nomor 1, Maret 2021, https://doi.org/10.31537/dedication.v $\underline{5 i 1.434}$ of teaching and learning process is changing rapidly before COVID-19's arrival. Students are to be attracted with online learning process and teachers are helped to improve their ability in teaching whether off-line or online. Technologies are made to help human's work, so it is not late for everyone who wants to learn and improve his/her ability in using the technology, especially for e-learning such as google classroom, edmodo, zoom application and so on. It is like an old saying that to be long life education for everyone

Pengabdian Masyarakat/LPPM) Sekolah Tinggi Ilmu Ekonomi (STIE) Sultan Agung Pematangsiantar, the Year 2020.

Thao, N. V., Herman, Napitupulu, E. R., Hien, N. T., and Pardede, H. (2021). CodeSwitching in Learning via Zoom Application: A Study in an EFL Context. Asian ESP Journal, Volume 17 Issue 3.1, March 2021, ISSN: 2206-0979, PP. 91111. Retrived from: https://www.asianesp-journal.com/volume-17-issue-3-1$\underline{\text { march-2021/ }}$

Tigowati, A. Efendi, and C. Budiyanto. (2017). The Influence of the Use of Elearning to Student Cognitive Performance and Motivation in Digital Simulation Course. Indonesian Journal of Informatics Education, Vol. 1. No. 2, 41-48

Zain, A. R. and Jumadi. (2018). Effectiveness of Guided Inquiry Based on Blended Learning in 
Physics Instruction to Improve Critical Thinking Skills of the Senior High School Student. In The 5th International Conference on Research, Implementation, \& Education of Mathematics and Sciences, IOP Conf. Series: Journal of Physics Conference Series, Vol. 1097, 1-6

https://unri.ac.id/wpcontent/uploads/2020/04/TutorialClassroom-untuk-Dosen-UNRI.pdf 